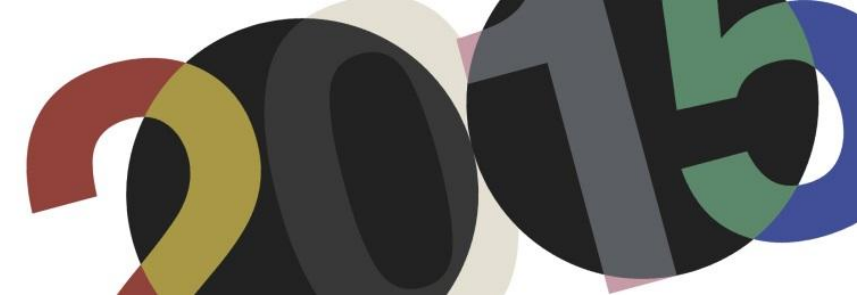

DOI: http://dx.doi.org/10.4995/LC2015.2015.895

\title{
THE INEVITABLE ORDER: Revisiting the Calibrated Biomimetics of Le Corbusier's Modulor
}

\author{
R. Itham Mahajan \\ Senior Architect, M/s. VBT Consortium, Bengaluru, India
}

\begin{abstract}
Biomimetics is a philosophy in Architecture that addresses issues not through mimicry but by understanding the rules governing natural forms. Biomimetics has gained popularity in the past few decades but it would be more apposite to state that this philosophy may have had its origins many years previously in the conceptualization of the Modulor, as Le Corbusier strived to unite Mathematics, Physiology \& Design. Common knowledge shows that disturbed by application of generic Imperial and Standard systems of measurements, the Modulor was ideated to help perceive the built environment as a physical extension of the human body. Le Corbusier's attempt to develop a harmonious scale towards the measurement of the absolute has been criticized for adopting industrial efficiency; though alienating human emotion was farthest from Corbusier's thought. What then is the architectural paradox in comprehending The Modulor as the universal proportioning system- racial differences in anthropometry, mechanizing architectural built forms within and without or simply an apprehension of losing mannerisms in architecture? Trying to unravel the mysteries of nature through analytics of the numbering system, Corbusier was consumed by the all-pervasive need to find answers to eternal questions in scientific spirituality. This paper explores the inevitable order of Le Corbusier's universe, revisiting the conceptualization of the Modulor, its relevance to architectural philosophies in general and Biomimetics in particular and the universal application of the same as a governing factor in Design methodologies.
\end{abstract}

Keywords: Le Corbusier, Biomimetic, Modulor, Universal Application, Design.

\section{Introduction}

Architectural design process necessitates the unified perception of synthesis, interpretation and analysis. Perennial debates revolve around the justification of theoretical exploration regulating creative processes. Departing from classical codes and established styles at the turn of the century, Design thought in general and Architectural contemplation in particular has been at the crossroads, attempting to arbitrate between pragmatic logic and transcendental deliberation. Design philosophers and visionaries passionately pursued this line of research, investigating assessment criteria for appreciating the intellectual aesthetic of human environments. One such Architect and Design philosopher set out to explore and expound the syntax of the architecture of the new era. Not convinced enough to affirm by the appropriateness of the Imperial and Metric system, this architect embarked on the quest for the eternal solution to decode the nature of spaces that influence physical comfort and sensory delight. He dedicated a life time in the pursuit of that universal key that integrates Human anthropometry and numbers applicable to generation of Biomimetic spaces, which relate at physical and metaphysical levels. Thus was born, Le Corbusier's Harmonious Scale of Measure, the MODULOR, to guide anthropocentric architectural thought, the world over. This radical proposal as regards Theory of Architectural proportions relevant to human habitation, credited to Le Corbusier may be considered the early years of inception of Biomimetic Architecture. 


\section{Inspiration}

The preoccupation of Le Corbusier with proportions could be traced back to his journeys throughout Europe during the formative years of his architectural training and his detailed study of ancient buildings. Leonardo da Vinci's depiction of the "Vitruvian Man" and Alberti's understanding of harmonic proportions were perhaps early inspirations, but gradually Le Corbusier's enthusiasm for ergonomics pertinent to spatial requirements for functionality culminated in a proportioning system that he called "the Modulor". During the early stages of conception of the Modulor, Le Corbusier favoured measurements, analogical to the Harmonic scales in his familiar field of music.

One of the pivotal chapters of Vers une architecture also dealt with 'regulating lines'1, a proportional grid used in designing buildings. This point was further illustrated with an elevation of Villa Schwob superimposed with a proportional grid.

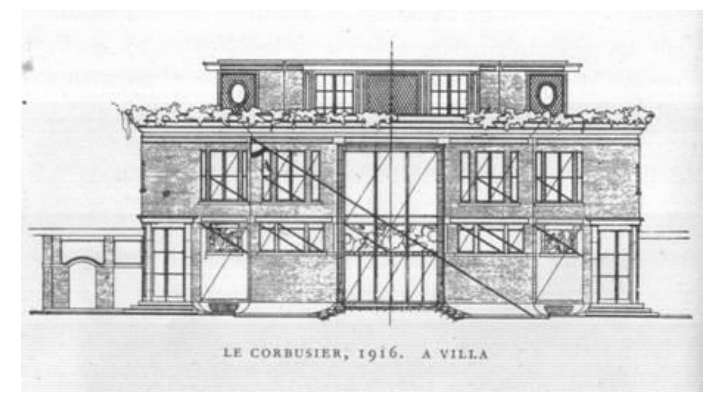

1. Le Corbusier, 'Regulating Lines', in Vers une architecture, 1924

The study of application of Regulating Lines in design and layout in the works of the Renaissance masters had no doubt inspired Corbusier also to develop similar principles. These may have set the preliminary stage for developing a harmonious proportional grid, having been inspired by Rudolf Wittkower's research into proportional systems in Renaissance architecture ${ }^{2}$, who himself was deeply affected by Panofsky's 1921 seminal essay on the 'History of the Theory of Human Proportions' ${ }^{3}$. Starting with geometric principles, universal to all fields of science and art, where relevant, Le Corbusier's inclination seems to have steered to the formulation of a specific code.

\section{Conception of the Modulor}

Many factors have influenced the conceptual evolution of the MODULOR. Modulor emerged as a reflective process through the confluence of the Golden Rectangle, Human anatomy and Mathematics. Corbusier's study of Ancient civilizations led him to believe that Architectural monuments belonging to bygone years also employed the mathematics of the Human body for design. He felt these buildings owed their grace to dimensioning system which employs the elbow (cubit), the finger (digit), the thumb (an inch), foot, pace and so on for measurement.

\footnotetext{
${ }^{1}$ Le Corbusier discusses how a villa of small dimensions designed with Regulating Lines gives the effect of being monumental amidst bigger buildings built without rule.

${ }^{2}$ Rudolph Wittkower's Architectural Principles in the Age of Humanism discusses proportions of The Palladian Villa.

${ }^{3}$ Franceso Benelli elaborates on Matter of Proportion.
} 

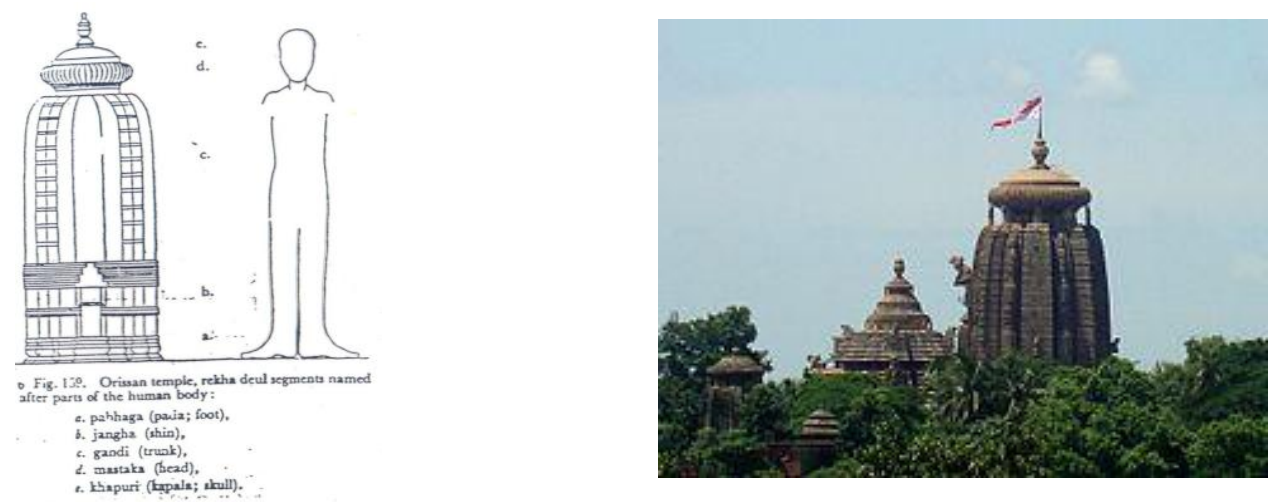

2. Parts of the human body in relation to Indian Temple Architecture ${ }^{4}$ (Source: https://en.wikipedia.org/wiki/Lingaraja_Temple)

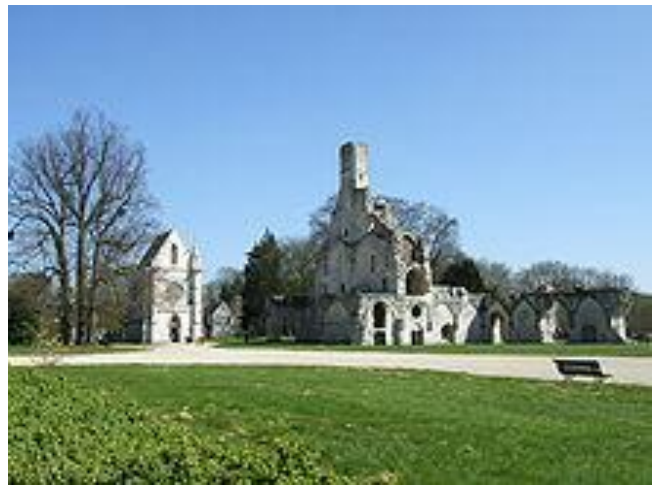

3. Moduloric proportions in The Abbaye de Chalis (Source: https://en.wikipedia.org/wiki/Chaalis_Abbey)

Detailed study of Egyptian, Greek and Indian Architecture showing specific relation to the human body and Corbusier's own on site experiments with The Abbaye de Chalis in the summer of 1948, whose measurements correspond to human proportions further encouraged him to work on a system of proportion based on Human Anatomy.

\subsection{INSPIRATION FROM THE DIVINE PROPORTION}

Le Corbusier was passionate about configuring a system of proportional measurement that would correspond to the subconscious requirements of the human body while incorporating the inherent aesthetics of the Golden Section. Universal standards corresponding to the integration of the human height based on divine proportion could form an ideal system of measurement. Spaces designed on this basis would be, he reasoned more functional and designers would be unable to produce impractical forms. Einstein himself has known to famously summarise the intent as being to create a "scale of proportions which makes the bad difficult and the good easy"

Though initially sceptical about the application of the Golden ratio to art, Corbusier's views did change dramatically following the publication of Matila Ghyka's influential book "Aesthetics of Proportions in Nature and in the Arts".

\footnotetext{
${ }^{4}$ Percy Brown's Indian Architecture (Buddhist and Hindu Period) discusses Temple Architecture in detail.

${ }^{5}$ Albert Einstein quoted in Modulor: 58
} 

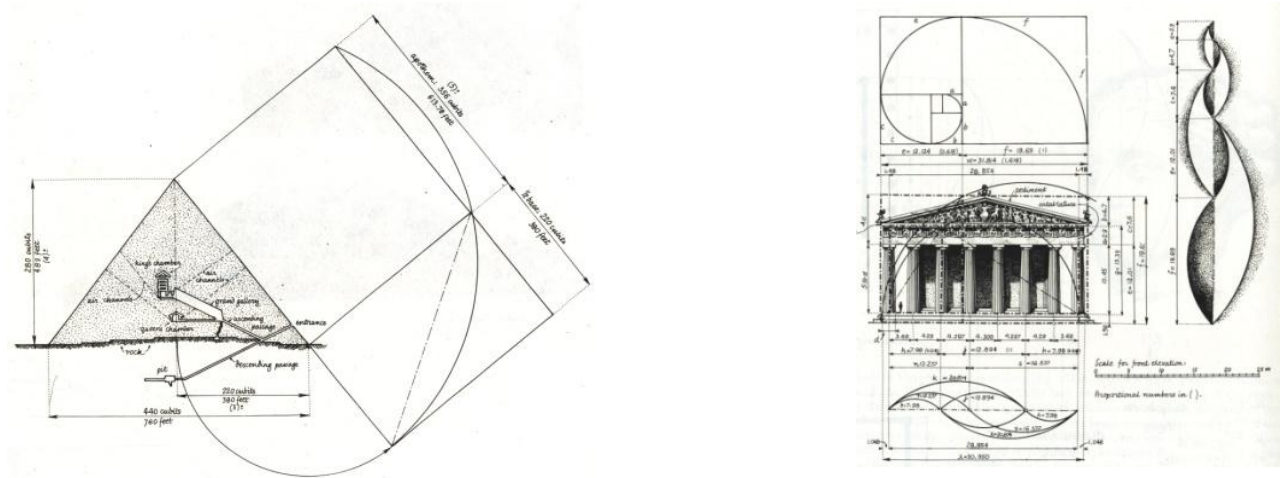

4. The Golden proportions in the Great Pyramid and the Parthenon ${ }^{6}$

Le Corbusier's absorption with the appreciation of aesthetics associated with the Golden Ratio could be linked collectively to his interest in phenomenology of basic forms and structures and his lineage that encouraged musical education, justifying his craving for a harmony achieved through numerical patterns. He is known to have felt that mathematics is the essence of his work due to his passion for architecture and music combined.

H.E. Huntley, author of the The Divine Proportion, explains that "the reason that we prefer visual aspects of a Golden Rectangle over a perfect square is measured in the amount of time it takes for the human eye to travel within its borders. This period of time is in same proportion (Phi) to the beats that exist in specific musical intervals. "7

\subsection{Pertinence to Human Anatomy}

The Modulor is a univocal attempt to overlay the proportions of the human body with geometry, similar to earlier attempts by Vitruvius. Comparable to the Vitruvian depiction of superimposed Euclidean geometry as an allegorical connection between humanity and architecture, Corbusier's Modulor also uses a Euclidean geometric overlay on the body for similar purposes. After much experimentation and through a process of selective elimination of the shorter French male and the curvaceous Female body, Le Corbusier settled on a six-foot-tall $(1.828 \mathrm{~m})$ English male body with one arm upraised. This was also adapted to ensure practical relevance to the feet and inches system of measurement ${ }^{8}$.

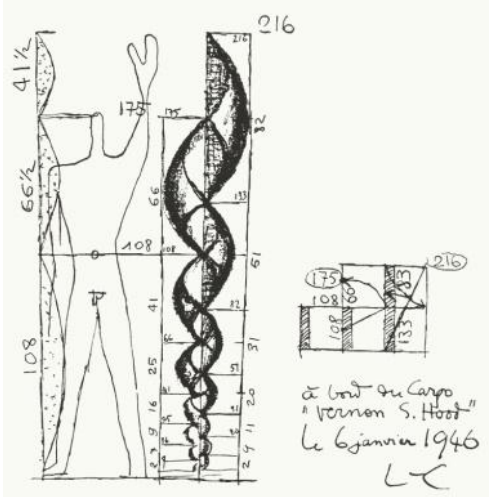

5. Corbusier's sketch of the Modulor integrating human anatomy with the Golden proportions.

\footnotetext{
${ }^{6}$ Gyorgy Doczi discusses Proportional Harmonies in Nature, Art and Architecture in The Power of Limits.

${ }^{7}$ H.E. Huntley elaborates on the aesthetics of Simple Mathematics.

${ }^{8}$ The Modulor strip as interpreted in The Modulor: 50
} 


\subsection{Integration of Mathematics}

The initial inspiration for the Modulor came from a vision of a hypothetical man inscribed with three overlapping but contiguous squares. In response to Corbusier's conundrum of 'this hypothetical man-with-armupraised, $2.20 \mathrm{~m}$. in height; put him inside two squares 1.10 by $1.10 \mathrm{~m}$. each, superimposed on each other; put a third square astride these first two squares', his assistant Hanning was to discern 'The place of the right angle'.

To solve Le Corbusier's puzzle, Hanning started with the central square and then generated a golden section arc from a diagonal of half the square in one direction and another arc from the diagonal of the full square in the opposite direction. These arcs then generate two new contiguous squares which are also defined by a rightangled triangle with its right angle passing through the common boundary between the two newly-formed squares. Mlle Elisa Maillard's alternative solution for Le Corbusier's problem initially produces a golden section from the starting square to generate the second square and then uses the diagonal of the newly-produced golden rectangle to form one edge of the right angle triangle. The remainder of the triangle generates the second square. Le Corbusier rapidly simplified Maillard's geometric solution to the three square problem and placed the human figure at its centre. He then used the vertical dimensions of these three squares which overlap to form golden rectangles, to produce measures that integrate human proportions and the Golden Section.
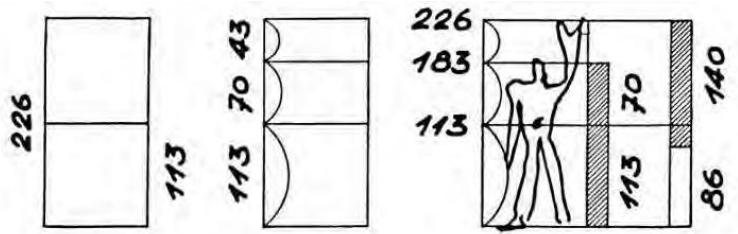

(220)

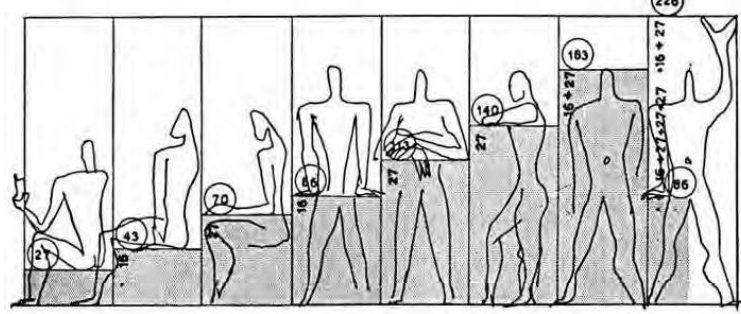

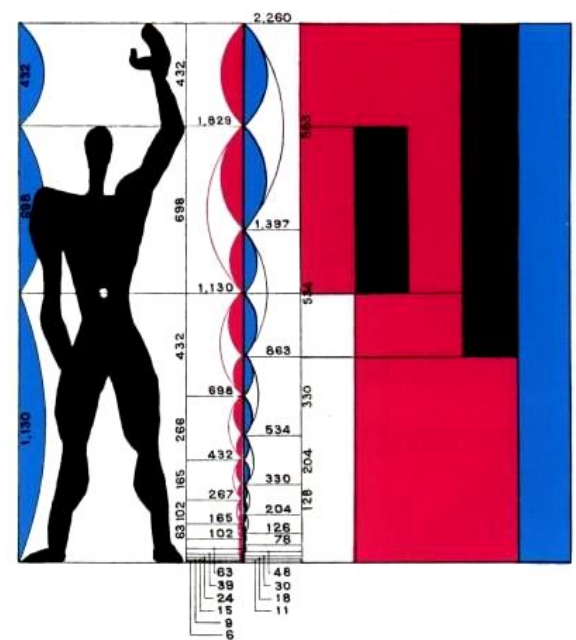

6. Corbusier's sketch showing basic Modulor dimensions and the Red and Blue series. (Source: The Modulor)

To accommodate varied dimensions and add versatility to the Modulor, Le Corbusier introduced the red series based on the unit 108, and the blue series based on the double unit 216. The Modulor strip now included the graphic of a man of height $1.75 \mathrm{~m}$ with arm outstretched engaged at four points, 0, 108, 175 and 216, the red series on the left and the blue strip on the right, the series going progressively from zero to infinity.

\section{Biomimetics and the Modulor}

Biomimetics as a philosophy in Architecture proposes to resolve issues and enhance performance in built spaces through an intensive research in Living systems. Corbusier could easily be credited with the Architectural application of functioning of one such living system - The Human Body. Corbusier's study was inclusive of not only ergonomic comfort as a design solution, but tended to transcend physical boundaries to relate to sensory perception and the Metaphysical.

\footnotetext{
${ }^{9}$ The Modulor : 37
} 


\subsection{The Modulor and Ergonomic Comfort}

Le Corbusier worked towards application of the Modulor in the volumetric spatial unit in the Unite d' Habitation in plan, interiors and facade detail. Le Corbusier considered the Pavillon de l'Esprit Nouveau a "minimum living unit" in which he also designed some Prefabricated Sectional Furniture based on the Modulor. Similarly, the design for the Unité d'Habitation has been acknowledged for having created a living-cell for a family with several children that enjoyed the visual and spatial expanse of a double-height living room, despite severe economic restraints. It was an accomplishment in the up gradation of social housing in post war France.

\subsubsection{The Modulor in Spatial Function}

The Modulor conceived to be applicable to Built environments may have been substantiated by Corbusier's study of "Objects meant to contain men, made to the measure of men". His graphic dimensional research of Railway carriages and cargo boats apart from the study of the intimacy and comfort of les petits apartments seemed to further validate the proposed dimensions of the Modulor.
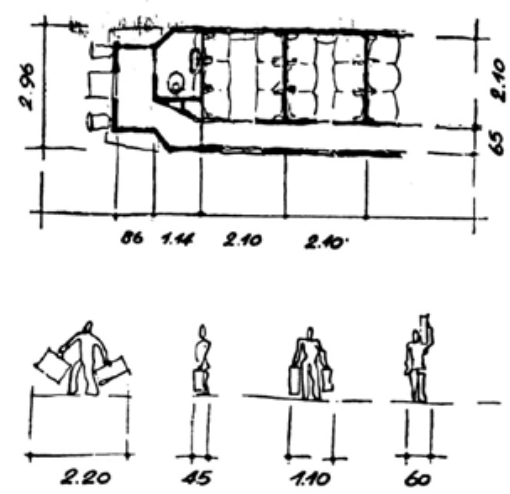

7. Corbusier's sketch of dimensional sketch of cargo boats and train carriage. (Source: The Modulor)

\subsubsection{The Modulor in Built Environment}

The façade of Unite d'Habitation is formed by a pattern of single and double height balconies generated from 15 different types of dimensions determined by the Modulor system. The rooms are $3.66 \mathrm{~m}$ wide and $2.26 \mathrm{~m}$ high or $4.84 \mathrm{~m}$ in double height. The framework is a module of $4.19 \mathrm{sqm}^{10}$.
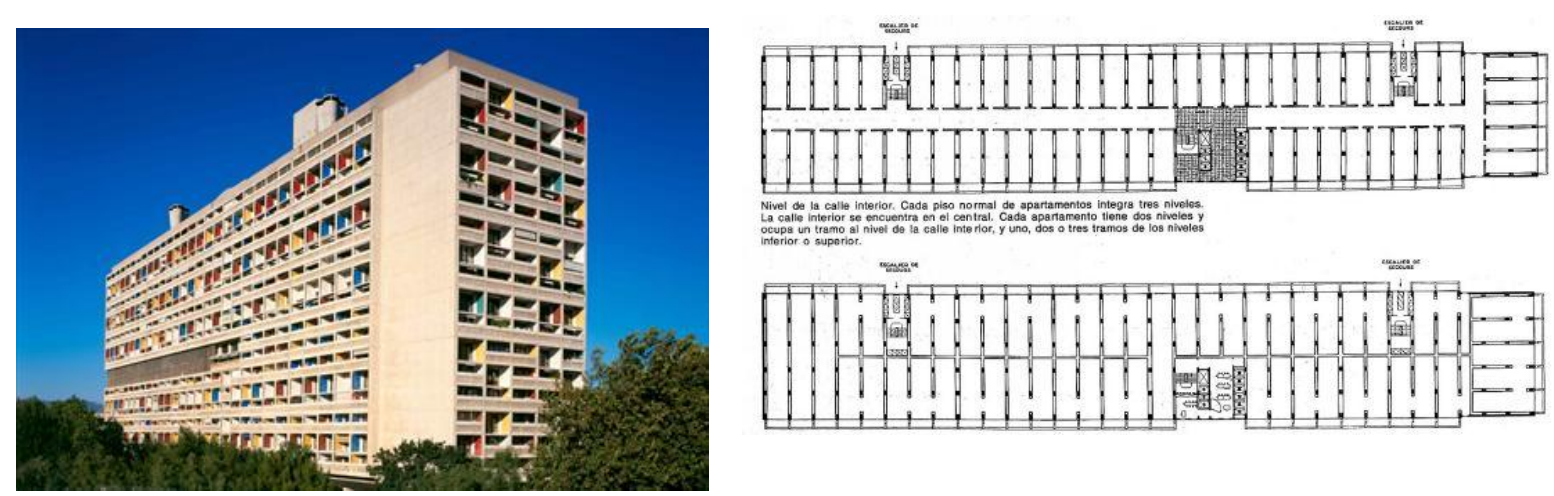

\footnotetext{
${ }^{10}$ Jean Jenger discusses Corbusier's work in the Architecture of a New Age :77
} 
8. The Modulor at Unite d'Habitation.

(Source: Unite d' Habitation, Marseille, Photo: Paul Kozlowski 1997- 1/1

(FLC-ADAGP)

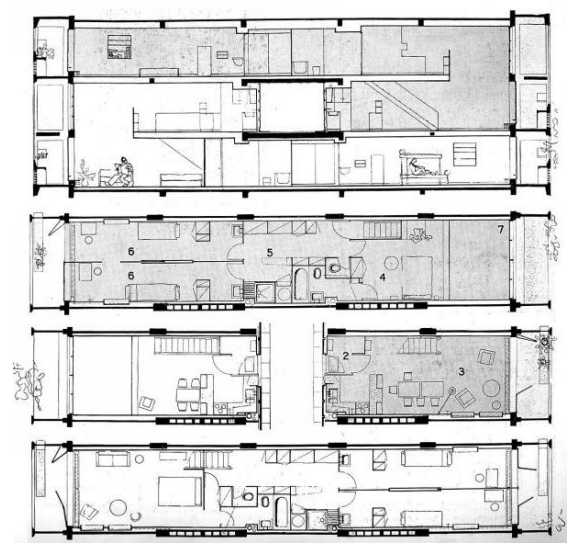

The design of the Jaoul houses built in Neuilly for two families with identical plans with all proportions based on Modulor was another experience to understand human centric dimensions to enhance order in Architectural design $^{11}$. Le Corbusier's cabin at Cap martin Square also incorporates a square plan of Modulor measurements 3.66 by 3.66 with a height of $2.66 \mathrm{~m}$.
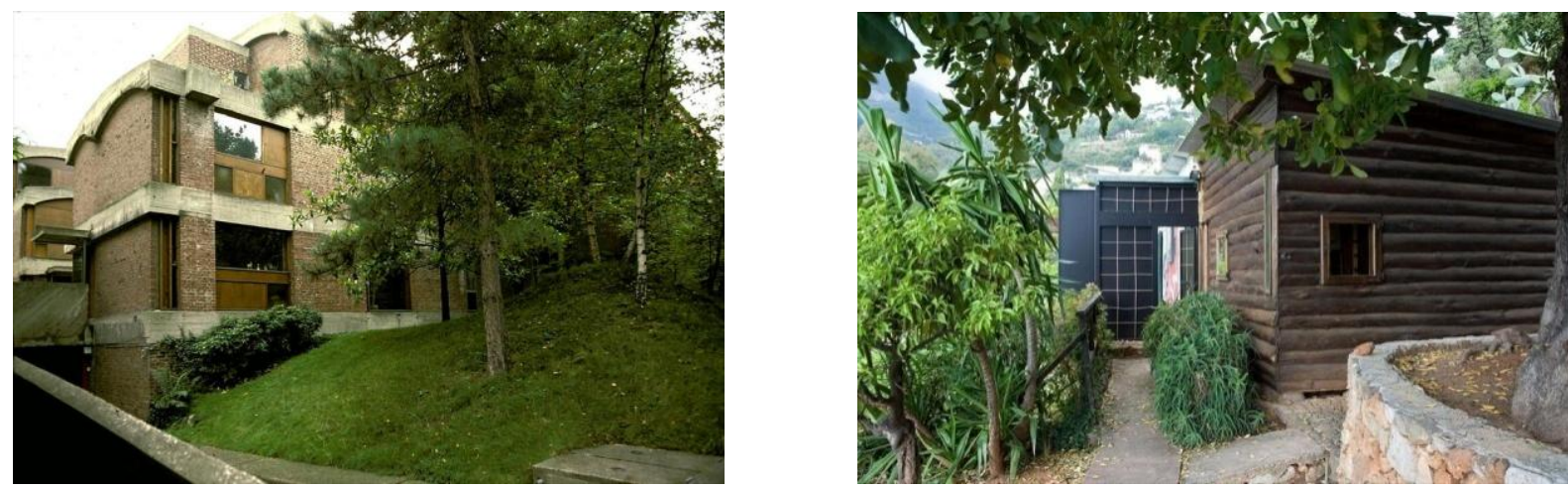

9. The Jaoul House (Source: Maisons Jaoul, Neuilly -sur- Seine 5/12 @FLC-ADAGP)and Le Corbusier's Cabin at Cap Martin square (Source: Cabanon de Le Corbusier, Roquebrune- Cap Martin, Olivier Martin - Gambier 2006 1/16 @FLCADAGP)

\subsubsection{The Modulor in Climate Control}

Le Corbusier's work in tropical climates helped ideate the invention of the brise-soleil . Clive Entwistle, the British architect, who translated several of Le Corbusier's books, wrote to him in August 1946: 'I take this opportunity on behalf of young people here to thank you for your latest gift to architecture: the brise-soleil, a splendid element, the key to infinite combinations. Now architecture is ready to take its place in life. You have given it a skeleton (independent structure), its vital organs (the communal services of a building), a fresh shining skin (the piloti). And now you have given it magnificent clothes, adaptable to all climates! You must be a little proud!' (Oeuvre Complete. Vol.IV.p113) ${ }^{12}$.

At the Secretariat, Chandigarh, Corbusier designed a linear layout to maximize natural lighting and crossventilation. In order to visually harmonise the scale, the immense façade of the Secretariat was designed using the Modulor to section it into visually decipherable elements through the brise-soleils to mitigate solar heat gain.

\footnotetext{
${ }^{11}$ Jean Jenger discusses Corbusier's work in the Architecture of a New Age :86

12 Christopher Mackenzie questioned the Corbusier's assumptions on a visit to India under Le Corbusier in the Sun in Architectural Review Archives.
} 


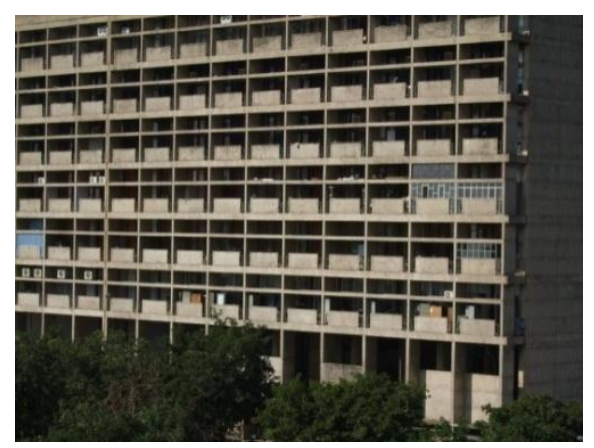

10. The Brise Soleil in The Secretariat, Chandigarh.

\subsubsection{The Modulor and Furniture Design}
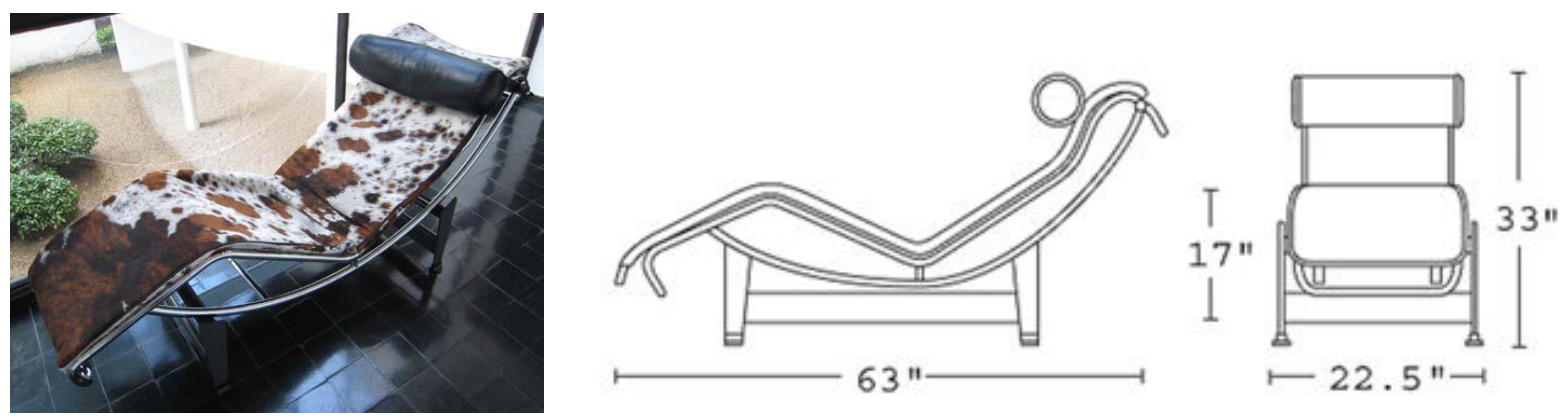

11. The Modulor finds Application in the Lounge Chair

The Modulor also finds application in furniture design. Le Corbusier Chaise Lounge Chair LC4 also corresponds to the spinal curve catering to ergonomic comfort. The height of the seating is $430 \mathrm{~mm}$, the dimension corresponding to the sitting posture of the Modulor man ${ }^{13}$.

\subsection{The Modulor and The Sensory}

Referring to the Modulor, Le Corbusier also propagates "the full-scale application of mathematics in building: three-dimensional urbanism (on the ground and in space)", adding that "measures enter into everything: pilotis, highways and roads, swimming pools, buildings, from top to bottom and in every object of the interior, car parks ..." 14 . The purpose of the Modulor was not limited to generation of anthropocentric dimensions for human habitation, but also needed to be inclusive of sensory perception related to psychological delight and comfort.

\subsubsection{The Modulor and Visual perception}

The visual perception of architectural form and appreciation of visual connect to the exterior surrounds must have been one of the foremost concerns in Corbusier's mind, so much so that an entire Section is dedicated to "The eyes that do not see" in his Towards a New Architecture.

\footnotetext{
${ }^{13}$ Tris Chris discusses the Modulor in a presentation on Proportion in Architecture, University of Hongkong.

14 The Modulor 1954: 168
} 


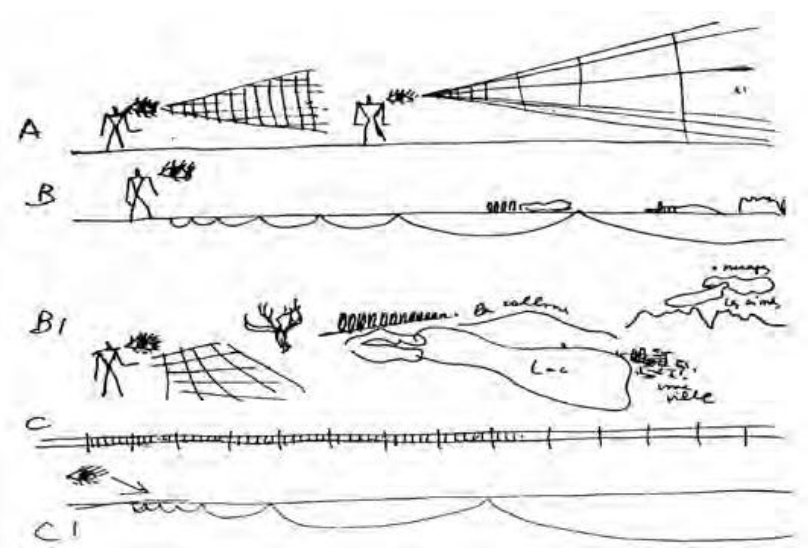

12. Visual Perception based on eye levels. (Source: The Modulor)

Fig.12 indicates the progression of harmonious scale $\mathrm{C} 1$ as against the simple arithmetic scale $\mathrm{C}$, which can be used to visualize the vista B1 inclusive of various elements of landscape, appropriate to cone of vision A1.

This is further collaborated by a letter from Le Lionnais, Mathematician ${ }^{15}$ who discusses the eye level of $1.6 \mathrm{~m}$ at which man 'establishes contact with the universe. His eyes look forward.....His life, then, is made up of a continuous sequence, succession, accumulation of visions'. M. Gabriel Dessus also writes: ' I believe as you do, that it is essential to have a scale.....This scale must be a geometrical series, because the eye appreciates relationships'.

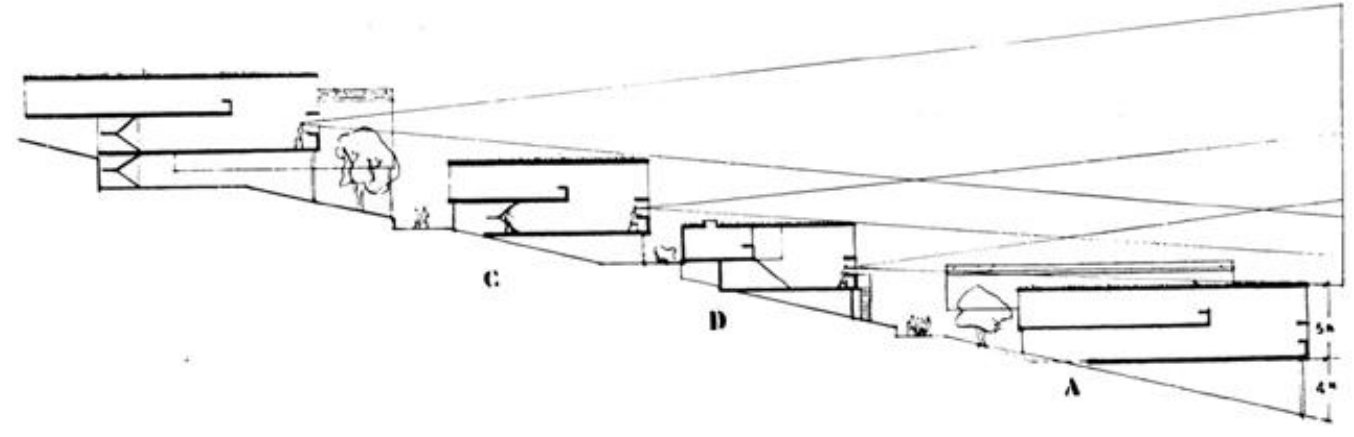

13. Roq et Rob at Cap Martin. Site section (Oeuvre complete, volume 5: 56).

\subsubsection{The Modulor and Psychological Comfort}

Le Corbusier also believed that the proportional system of the Modulor encourages psychological association owing to space related to the dimensional requirements for a said activity aligning physically with the human body. In support of this, Corbusier also claimed architecture "as a part of the mechanical system that surrounds us and functions as an extension of our limbs...its elements, in fact, artificial limbs".

\footnotetext{
${ }^{15}$ Modulor 2: 18
} 


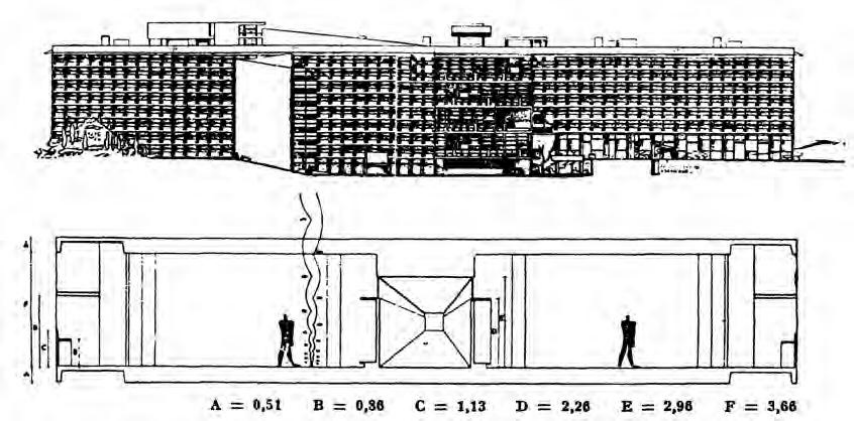

14. Spatial volumes configured to Moduloric Dimensions (Source: The Modulor)

The inner dimensions of the Secretariat at Chandigarh adopted Moduloric proportions to generate spatial volumes relating to the activity zone concomitant with human comfort.

Tapestries in the Court of Justice in Chandigarh are another example of visual relief through appreciation of certain proportions. These tapestry designs referred to the architectural plan with special emphasis on Le Corbusier's adulation of the right angle as fundamental element of order and the Modulor.

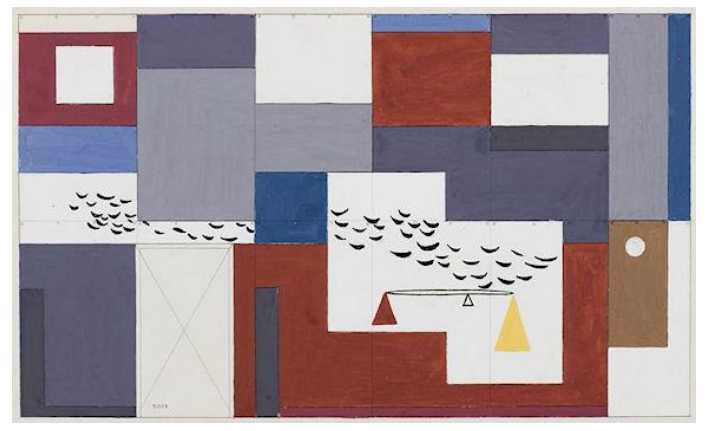

15. Tapestries in Court of Justice in Chandigarh based on Modulor proportions.

Though the tapestries were created for acoustical purposes, they would also serve as a psycho-physiological stimulant. Further, each of the tapestries was a structured composition of several rectangular units with a standard width of 4'-7", corresponding to that of the loom.

In one of his later projects, Le Corbusier's proposed design for a hospital in Venice in 1964 assigned to each patient, a 'unite lit', a spatial module of $3 \times 3 \mathrm{~m}$ with a glassed opening of $3 \times 1 \mathrm{~m}$, placed above a ceiling of $2.26 \mathrm{~m}$ height. The glass opening will project light on a curved wall $3.66 \mathrm{~m}$ high. The light thus projected and diffused into the spatial enclosure of Modulor proportions was meant to enhance the therapeutic environment.

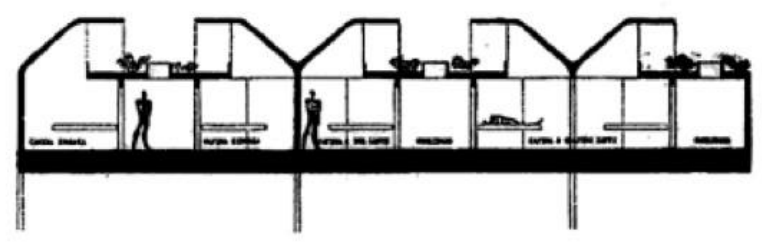

16. The Unite Lit in Venice Hospital

\subsection{The Modulor and The Metaphysical}

It is not difficult to comprehend that the Modulor was not meant to be just a scheme of numbers to apply or a set of rules to abide by. Corbusier wanted the Modulor to relate at sub conscious and super conscious levels. As the 
pages of the Modulor turn and the volume nears the end, the intellectual fervour which engulfed Le Corbusier to personify his design deliberations becomes relatable.

\subsubsection{The Modulor and Music}

Xenakis discusses the rhythmic articulation of the pans de verre ondulatories through modulor dimensions which was generated through a combinatorial number system used for syncopation of these elements similar to the system for orchestrating his composition "metastasis". This is also evident in the glissandi form in Philips pavillion, Brussels world fair $1958^{16}$.

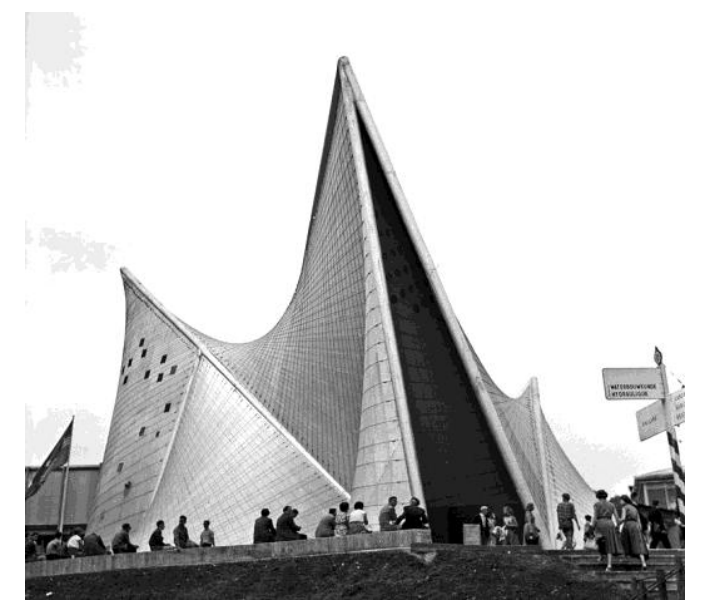

17. Glissandi form in Philips Pavilion, Brussels World fair (Source: "Expo58 building Philips" by Wouter Hagens - Own work. Licensed under CC BY-SA 3.0 via Commons -

https://commons.wikimedia.org/wiki/File:Expo58_building_Philips.jpg\#/media/File:Expo58_building_Philips.jpg)

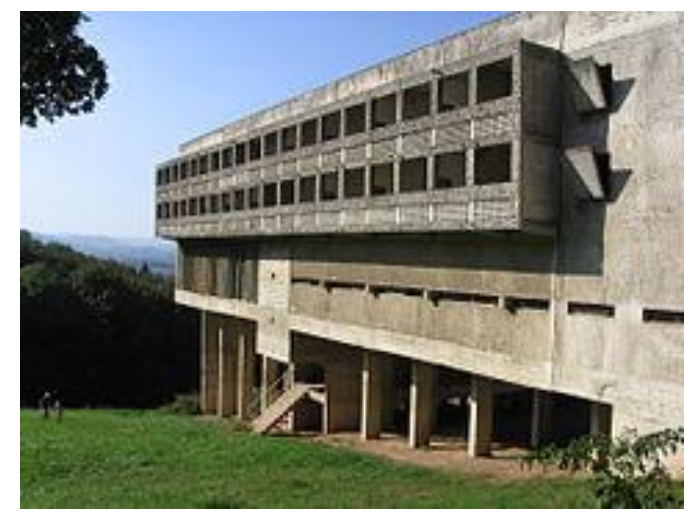

18. Pans de verre Ondulatories through Modulor dimensions (Source: "Sainte Marie de La Tourette 2007" by Alexandre Norman - French Wikipedia. Licensed under CC BY-SA 3.0 via Wikipedia -

https://en.wikipedia.org/wiki/File:Sainte_Marie_de_La_Tourette_2007.jpg\#/media/File:Sainte_Marie_de_La_Tourette_2007. jpg

\subsubsection{The Modulor and Esoteric}

Eminent architect \& critic Kenneth Frampton also discusses the similarity between the most important dichotomous figure in the alchemical cosmos, Mercury and the abstract scale of interlocking blue and red

\footnotetext{
${ }^{16}$ Kenneth Frampton elaborates on the application of the Modulor through Xenakis' works in Le Corbusier:181
} 
proportions of the Modulor. Similar references to the mythical ascension of pagan Mercury from earth to sky and descending again as part of the continuous cycle is also evident in Corbusier's moving account of cloud formations while flying over Pampas.

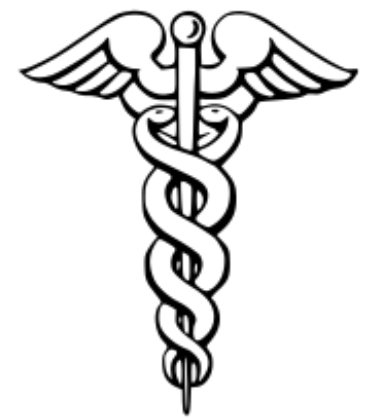

19. Mercury's Caduceus bears a strange resemblance to the Modulor strip (Source: https://en.wikipedia.org/wiki/Caduceus)

\subsubsection{The Modulor and Higher level of meaning}

The higher level of meaning associated with the Modulor further intensifies as we approach 'The Poem of the Right Angle'. The panel A3 depicting the upright Modulor as the procreator with reference to the earth and the cardinal symbols, the alchemical rota or wheel representing the 4 seasons.
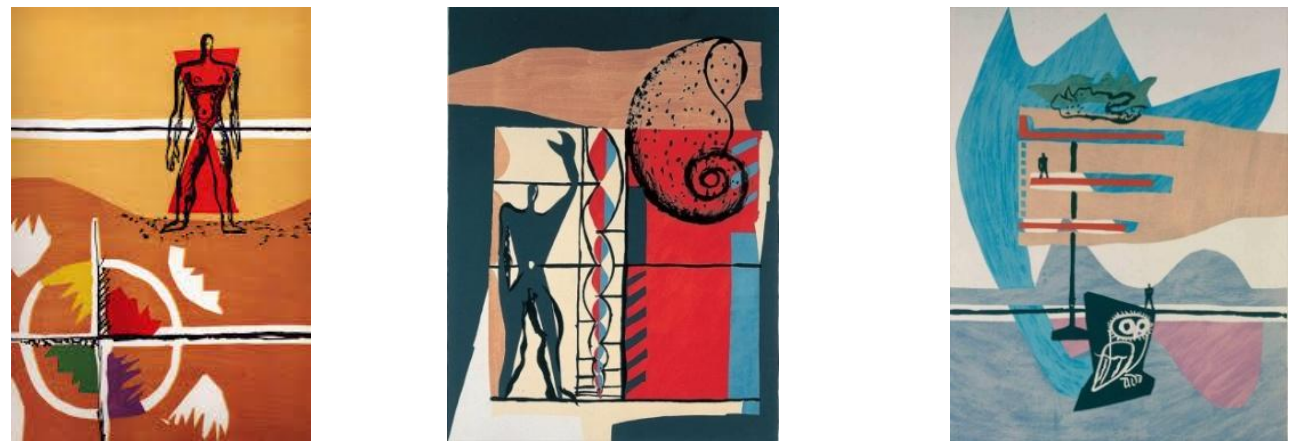

20. The Modulor in A3, B2 and B3 panels of The Poem of the Right Angle.

The Modulor further appears in panel B2 juxtaposed with a shell symbolic of golden proportions. In panel B3 in an architectural frame comprising of floor plates and foundation placed atop an irregular field surrounding the white line image of the wise owl, emerges a Modulor man cleared of obstacles.

The poem of the right angle is a window to the philosophical significance of the Modulor man in Corbusier's thought. The Modulor to Le Corbusier was not just a proportion. Famously referred to as his Alter Ego, Corbusier's Modulor seems to be an extension of his spiritual self.

\section{Possibilities and Limitations}

Panel exercises ${ }^{17}$ proving the versatility of the Modulor as a design tool have been chronicled. The sometimes overly perceived cubist application of the Modulor has also been addressed in the configuration of 'light-funnels' in the south wall of the Ronchamp, irregularly arranged but forming a unified composition by the 'Modulor' system as an expression of the human values depicted in the wall.

\footnotetext{
${ }^{17}$ Modulor 2: 92
} 
Corbusier says "It is a working tool for those who create and not for those who execute"18.

The Modulor has been criticized however for rendering very impractical values to smaller dimensions and not favouring ease of construction. This explains the selective use of this scale in architecture and its brief yet impactful brush with popularity.

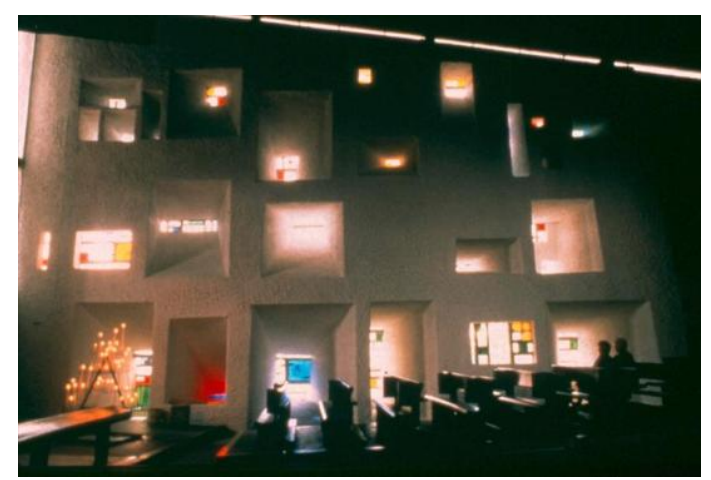

21. Light Funnels in Ronchamp (Source: Chapelle Notre Dame du Haut, Ronchamp, Photo: Paul Kozlowski 8/15 @FLCADAGP )

Corbusier does argue that all references at the Unite d' Habitation are based on just fifteen different measures based on the Modulor reducing complexity in dimension. Further, he adds that work inside the building can be completed without scaffolding even in the double height spaces with a maximum height of $4.85 \mathrm{~m}^{19}$. Corbusier's Cubist and Brutalist style of Architecture did find many protégés but however even his most ardent followers could not find full application of the Modulor in their works.

\section{Reflections}

As a parallel to publishing scientific findings, the following queries do arise in researched thought elaborating on the significance of the Modulor, the inspiration, the conceptualization and the application.

- What would be the impact or relevance of the adaptive or approximated Modulor in the current Market regulated Architectural scenario where urban real estate economics is governed by escalating unit rates and land prices? Can commerce driven Architectural practices with tight deadlines and stringent budgets accommodate the Modulor in their Design methodology or Construction practices? Every square inch needs to be accounted for in the built up areas as per regulatory bodies and priced for commercial gains.

- As a sensory perception of space, will using the Progressive scale of measure help produce a harmonious unified composition as opposed to the Linear scale which is manipulated as a number rather than a relationship, limited by the dimensions of the drawing interface? The metre or the Kilometre can both be represented by 1 Centimetre, it all depends on the size of the drawing sheet.

- Enfin, validated by various mathematical studies, lauded by philosophers and approved by commercially successful establishments, is it not surprising that the Modulor was not awarded the status of a unit by itself like the Kelvin or Ampere, honouring the inventor, instead of necessitating the reconversion to the metric or imperial system?

\footnotetext{
${ }^{18}$ Modulor 2: 178 ( In reply to John Dale)

${ }^{19}$ Modulor 2: 124
} 


\section{Conclusion}

Corbusier's faith in the mathematical order of the universe, his tryst with the divine proportion and his obsession with anthropocentric measurements did result in the harmonious scale of the Modulor. Its application has received bouquets and brickbats alike. But with an intent so pristine, a scientific approach so well researched, an intensity so fervent and a path breaking ideology so intellectual, it is not difficult to comprehend that Le Corbusier's innovation can elevate any design idea into a work of art. With the Modulor guiding the design process, it is impossible to not tune into the inevitable order of the universe with the human spirit at the epicentre. As Corbusier says "The Modulor is a tuned piano. Play it well"20.

\section{Bibliography/References}

Benelli, Francesco, Rudolf Wittkower versus Le Corbusier: A Matter of Proportion journal.eahn.org/articles/10.5334/ah.ck/2013

Brown, Percy, Indian Architecture (Buddhist and Hindu Period), 2nded, w/o.pl. : Tobey Press, 2013, ISBN 1446510212 (ISBN13: 9781446510216 )

Corbusier Le, Towards a New Architecture, New York: Dover Publications Inc, 1986, ISBN: 0486250237 (ISBN13: 9780486250236)

Corbusier Le, The Modulor, 2nded, Basel: Birkhauser GmbH, 2011, ISBN: 3764361883 (ISBN13: 9783764361884)

Corbusier Le, Modulor 2, 2nded, Basel: Birkhauser GmbH, 2011, ISBN: 3764361883 (ISBN13: 9783764361884)

Corbusier Le, Le Poeme de L'angle Droit, w/o.pl :Hatje Cantz Publishers, 2012, ISBN: 3775734708 (ISBN13: 9783775734707)

Chris Tris, Proportion in Architecture-University of Hongkong, Faculty of Architecture.

Doczi, Gyorgy, The Power of Limits: Proportional Harmonies in Nature, Art, and Architecture, w/o.pl. : Shambhala Publications, 2005. ISBN: 1590302591 (ISBN13: 9781590302590)

Frampton Kenneth, Le Corbusier: Architect of the Twentieth Century, New York: Thames \& Hudson, 2001, ISBN: 0500203415 (ISBN13: 9780500203415)

Jenger, Jean, Le Corbusier - Architecture of a new age (New Horizons), w/o.pl. : Thames \& Hudson, 1996, ISBN: 0500300674 (ISBN13: 9780500300671$)$

Joshi, Kiran Prof., Urban and architectural work of Le Corbusier in Chandigarh, Department of tourism, Chandigarh administration, Chandigarh, India, Oct 2006

Mackenzie Christopher, Le Corbusier in the Sun, Architectural Review Archives.

Payne, Alina A., Rudolf Wittkower and Architectural Principles in the Age of Modernism, Journal of the Society of Architectural Historians, Vol. 53, No. 3 (Sep., 1994), pp. 322-342: University of California Press on behalf of the Society of Architectural Historians.

${ }^{20}$ Modulor 2: 130 